\title{
Searching for a New Engineer
}

\author{
Claudio da Rocha Brito, Melany M. Ciampi \\ University Center of Lusiada
}

\begin{abstract}
The era of wild fight for new commercial markets has started after the disintegration of Socialist Bloc. So Economic Blocs have emerged in order to face this new global economy. In this context Mercosul has raised up in South America, which participating countries are Brazil, Argentina, Paraguay and Uruguay. The creation of this Bloc has a strong incidence in education, which is foreseen in the agreement signed by Common Market Council, which had place in Las Leñas in June of 1992. The plan proposed by the education ministries of the four Countries demands the application of a harmonic education system so that the instruction is equivalent in the four Countries. Taking into account this and other aspects of this new world the Engineering Faculty
\end{abstract}

of University Center of Lusiada has elaborated an Engineering Course, which propose is basically the adoption of some subjects of Humanities and Social Sciences, among others. The chosen subjects are Philosophy, Human Resource, Development of Projects, Assisted Training Period, Management Strategies and since 1999 the subject Sociology was included to enrich the course principally because it is a Science that shows and discuss the main aspects of men life in Society. It discusses the importance of some social rituals for a living and the seeking for social justice. The goal is to form Engineers with good skills more creative, more critics and more attempt to the quick transformations in every aspect of professional life integrated to the new connected and global world. This experience has showed good results and has also brought up the changes in the way of seeing the Engineer as an agent of Science and Technology development for the well fare of humanity.

\section{Introduction}

It is legitimate to say that globalization expresses a new wave of Capitalism expansion as a producing way and a civilizing process in a wide level. The 180 Countries in the world approximately 100 of them receive together around only $1 \%$ of direct foreign investment. This is only an indicator of the gap each time bigger that in according to recent report of World Bank separates the rich Countries to the poor ones in the globe. By the social point of view, the globalization has been the inseparable partner of a gigantic raise of polarization between Countries and classes and also by the point of view of richness the distribution of profits and jobs. 
Penetrating easily in international markets the developed Countries close their door simultaneously to the competition of what are called "peripheral Countries", raising the concentration of richness and accelerating the discrepancies in funds distributions.

The negotiations about global commerce that seem to be so distant of common citizen's day by day have a straight influence over social scene of Nations.

To the education Institutions the challenge consists in getting a new professional. To the engineering colleges the challenge is to form engineers capable to act in this new world order where engineering is so important even more for the "peripheral Countries". There is a necessity of good engineers researchers to develop technology and at the same time committed with environment so important for the future of all Nations ${ }^{1}$.

The formation of engineers is crucial for countries like Brazil, that is a large country full of natural resources with a huge potential. The education institutions worried about the future of the country have been discussing the profile of the new engineer taking into account the South America Economic Bloc the Mercosul which plan proposed by the Educational ministers of the four Countries demands the application of a harmonic school system so that the instruction is equivalent in the four Countries.

Some Colleges like Engineering College of University Center of Lusiada has developed a Project in Engineering Education that considers not only the global changing but also the new educational policy which has been implemented by Science and Technology Ministry of Brazil.

The Project is the new program, which has a curriculum with extra courses of Social Sciences. The objective is to form engineers committed with the seeking for society well fare in which s/he is inserted.

\section{Lusiada University Center}

In 1967 the Lusiada Foundation was created and it started its activities with the Medical Science College.

In 1969 Management College began and after having consolidated the two Colleges, other Colleges has come. Finally in 1993 the Education Ministry of Brazil recognized the Lusiada as a University Center.

The main characteristic of University Center of Lusiada is the preoccupation with the excellence of education that it offers. This characteristic is expressed in its modern and well-equipped laboratories, libraries and research centers.

Besides a high level of Faculty with 400 members, the University Center of Lusiada also maintains services to the community. By an agreement between the University and the city Hospital, the "Guilherme Alvaro Hospital" can receive around 11 thousands patients per month. 
It has 220 places and 22 are reserved for Aids patients. All its Research Centers develop a kind of work to the community, which enriches their work too ${ }^{2}$.

\section{The New Paradigm}

The urgent challenge of education institutions presently is to discuss and find solutions for the equation: What is necessary to form professionals ready to face the competitiveness in according to the new paradigm of complex, mutable and uncertain work environment? Or what to do to change it all?

In a new era, which the supremacy of information and the knowledge are widely preached, the formation of a professional becomes a crucial factor for success.

The new paradigm preaches that the capital is the intellect and people are the most important, but by the other hand it is still difficult the total absorption of this new model of development. Why? Because there is the natural resistance of a person to re-structure her/himself cognitively and emotionally making possible the learning and principally the creation of concepts completely new.

In according to Galbraith the decades of 80 and 90 marked the rough change of an increase era and plentifullness to another, which the only constant is, the uncertainty. The work of Naisbitt and Aburdene of $1982^{3}$ they pointed some of the main global transformations that could occur in the nineties. Among others they pointed the evolution of an industrial society to a society of information and high tech; the globalization of the economy; the end of cold war and the fragmentation of soviet bloc generating a new world order multipolar; the poverty; inflation and others. The list does not end here and others will come like for instance, in the fields of science and technology, environment, social, cultural and demographic.

So following these tendencies the engineering education institutions in Brazil are, let's say, running fast to form a new engineer. New programs have been conceived, new approaches, new laboratories and so on. Changes have been happening and many of them are successful.

Lusiada's program for engineering education is one of the successful new kind of forming good engineers prepared to face next millenium.

\section{Present State of Engineering Education in Brazil}

In Brazil engineering education has been passing through a deep and large discussion about the formation of engineers for next millenium ${ }^{4}$.

Recognizing the importance of engineering in world scenery Brazil has been working to get and keep the competitiveness of national goods and services by means of projects of qualification of professionals through continuing education for example and others. Many representative groups, leaderships and agencies have been implemented programs to prepare the engineers to increase the efficiency of research system, experimental development, engineering, producing system and 
market. So many engineering education institutions have not only discussed but also implemented new strategies and different curriculum for the engineering programs ${ }^{5}$.

Some of these strategies are:

- researches having enterprises as partners;

- more practicing during the program;

- creation of "Junior enterprises";

- promotion of events in the areas, in academic level, accessible to the students.

And the discussion is still opened up in a process of constant renewing of the formation of a new professional ready to face the mutating work market of the future ${ }^{6}$.

V. The Engineering Education Project

The coordinating team has decided that the following courses could be included in the Engineering Programs of University Center of Lusiada: Philosophy; Development of Projects (in the different Levels); Assisted Training Period; Human Resource and Management Strategies and recently Sociology ${ }^{7}$.

All distributed along the five years program in a way that they can be moved without any loss to the program.

These courses allied with the Basic Science Courses can provide to the students a new view and a new way to face and overpass the challenges of the new century work market ${ }^{8}$.

\section{About The Courses}

To get the good results in according to the goal of the program the contents of the courses were elaborated in a way to avoid unnecessary information not to overload the students and also to keep their interest. The objective is basically to stimulate the creativity of the students and the adoption of strong Ethic models ${ }^{9}$.

The Philosophy - that is the study and the creation of theories about basic things such as the nature of existence, knowledge, thought, or about how people should live - is very important principally because it is a great opportunity to the students to discuss all those matters. Socrates, Plato and Aristotle for example, give them a whole spectrum of political philosophies.

This course will provide the students not only how to deal with others ideas but also to increase their creativity, that is fundamental for any activity. Besides it enriches the conception of Ethic that is so important to the development of Science and Technology in according to environmental necessities.

Human Resource shows and discuss behaving topics in human resources management, offering the students the most recent aspects of it, as well as to put them in touch with executives of enterprises by means of meetings and talks. This course presents the students how to deal with 
people while human being, mates, consumers and clients, learning about the human resource management in different realities in different organizations. They can view a whole universe of possibilities and success since they learn about their own limits besides to learn how to work as a team.

Development of Projects can count with an advisor Professor who accompanies the student, since first year of College. This course gives the students the designing, the execution and the interpretation of the results of a project. It can be a little hard in the beginning because of the lack that exists between second grade formation and College formation. Anyway they learn how to propose, to develop and to present their projects, which is an important achievement for their carriers in the future. When they finish the course they will be able to report to everyone with confidence no matter the number of people they have to do it.

Assisted Training Period, which is basically the experience of working in an Enterprise. The students work effectively fulfilling a schedule developed by both, the Faculty and the Enterprise. The student is assisted by a Professor and a supervisor or coordinator until to complete the work. This course gives the practical experience that show the students not only the "know how to do" and the "why to do" but also the practice.

Management Theories provides the future Engineer skills of Management Theories, the old and the newest ones. They have a wide discussion about the latest models of strategies and as much as possible, the opportunity of applying some of them in practical exercises. This is an important course considering that a big amount of Engineers has to deal with management.

The main objectives as related above are to give the students the basic knowledge about Philosophy and Science and the development of a strong Ethic ${ }^{10}$.

Sociology was included to enrich the course. It is a Science that shows and discusses the main aspects of man's life in society. So it is supposed to increase the notion of some social rituals for a living, their importance and consequences ${ }^{11}$.

The evaluation criterion is up to the Professor responsible for each course. It can be done by means of works, seminars and tests or any other method. This flexibility is important because of the objective of the courses, which is to give the student an opportunity to meditate and think about and not only to achieve knowledge. Like the others courses a minimum score is required to the approval for next year ${ }^{12}$.

Besides good faculty members the students can count with well equipped Libraries, Internet access and a staff specially trained for helping.

VII. Distribution of the Courses

As mentioned before the courses are offered along the program of five years and the following distribution was adopted so that the students have:

- Philosophy in the first and second years; 
- Development of Projects and Assisted Training Period in the last year;

- Human Resources and Management Strategies in the third and fourth years respectively;

- Sociology in the last year.

The distribution suggested was conceived taking into account the considerable number of Basic Science Courses of Specific areas of Engineering which are essential ${ }^{13}$.

The distribution of the courses has been modified because it is part of the flexibility of the program; changes are made so the students can get a better performance. Development of Projects for example, in according to them, it works better if it is only in the last year ${ }^{14}$.

The goal is to improve the Engineering Education, modifying those aspects that make the course so much and only technical. And it has to be made without overload the just heavy and tight schedule of most Engineering Courses ${ }^{15}$.

VIII. First Numbers of the Program

The numbers mentioned bellow refers to the first year of the implemented program. As it is a special kind of education it is interesting to have these informations so that in the future it is possible to make comparisons.

In the first year there were 40 students 16 were women.

In the second year of the program there were 24 students and 10 were women.

In the third year there were 23 students and 9 were women.

For the $4^{\text {th }}$ and $5^{\text {th }}$ year this numbers has been the same of third year.

The high level of retention has been solved by a new distribution of subjects and also by a scheme of monitoring much more dynamic and flexible.

\section{Conclusions}

This mutating world has been driving people, society, institutions and countries to a race for surviving hard to follow. People and enterprises have to follow and overpower the scientific and technological development. If not, people as professionals become obsolete, the enterprises loose market and Countries get underdeveloped becoming externally dependent of the most strategic acquisition of modern world, the knowledge ${ }^{16}$.

Presently the definition of qualification is as mutable as the work market so it is difficult to get a point of reference about what is necessary to get and keep a place in the global work market.

This paper has the goal to show an experience that has been developed in engineering program of University Center of Lusiada and which has succeeded considering the present social, 
economic and policy aspects of Brazil. An engineer with a strong ethics and committed with environment. This new kind of program has also contributed a lot to the discussions and searches for engineering education in the Country.

The flexibility of the program provides one of the most interesting aspects of it. So every year a questionnaire is applied for both students and Professors. The goal is to obtain information about the quality of the extra courses of the program so that modifications can be done, if and when they are necessary.

Bibliography

1. Fiori, J. L. 1997, Globalização e questão do trabalho no Brasil, O Social em questão, Rio de Janeiro, v.2, n.2, p.

7-15, jul./dez.

2. Lusiada, F: "Centro de Estudos Superiores da Fundação Lusiada", Santos: UNILUS. 1994.

3. Naisbitt, J.A. Megatrends 2000: Ten New Directions for the 1990's. New York: AvonBooks, 1999. 416p.

4. Brito, C. da R.; Brito, M. M. C. T. da R. "The Engineering Education in the new era", In: Interamerican

Conference on Engineering and Technology Education, 5., Rio de Janeiro, 1998. Proceedings INTERTECH - 98.

Rio de Janeiro: INTERTECH, 1998. p. 15-19.

5. Brito, C. da R.; Brito, M. M. C. T. da R. "A New Engineer for a New Global Market”, In: International

Conference on Engineering Education, 2., Rio de Janeiro, 1998. Proceedings ICEE - 98. Rio de Janeiro: ICEE, 1998. (in CD-ROM).

6. Brito, C. da R.; Brito, M. M. C. T. da R. "El Ingeníero y el Nuevo Mercado de Sudamérica", In: Congreso Argentino de Enseñanza de Ingenieria, 2., San Juan, Argentina, 1998. Resumenes. San Juan: CONFEDI, 1998.

7. Brito, C. da R.; Brito, M. M. C. T. da R. "The Forming Humanistic in Engineering Education", In: American Society of Engineering Education Annual Conference, 106., Charlotte, 1999. 1999 ASEE Annual Conference Proceedings. Charlotte: ASEE, 1999. (in CD-ROM).

8. Brito, C. da R.; Brito, M. M. C. T. da R. “An Innovating Proposal to Engineering Education”, In: International Conference on Engineering Education, 3., Ostrava, 1999. Proceedings ICEE - 99. Ostrava: ICEE, 1999. (in CDROM).

9. Brito, C. da R.; Brito, M. M. C. T. da R. "Different Teaching Scheme of Education for Engineers", In: International Conference on Engineering and Computer Education, 1., Rio de Janeiro, 1999. Proceedings ICECE 99. Rio de Janeiro: ICECE, 1999. (in CD-ROM).

10. Brito, C. da R. "La Formación del Profesional de Ingeniería y los desafíos de la Nueva Realidad Mundial", In: Reunión Nacional de Facultades de Ingeniería, 19., Cartagena de Indias, 1999. 1999 Ingeniería, Calidad y Desarrollo. Cartagena de Indias: ACOFI, 1999. p. 341-346.

11. Brito, C. da R.; Brito, M. M. C. T. da R. "Flexibility and Dynamic in Engineering Course", In: Referate des 28. Internationalen Symposiums "Ingenieurpädagogik'99", 28., Istanbul, 1999. Das Studium des ingenieurwesens im dritten millenium. Istanbul: IGIP, 1999. (in CD-ROM).

12. Brito, C. da R.; Brito, M. M. C. T. da R. "Adoption of new subjects to improve the formation of future engineer", In: Frontiers in Education Annual Conference, 15., San Juan, 1999. 1999 FIE Annual Conference Proceedings. San Juan: FIE, 1999. (in CD-ROM).

13. Bryan, N. A. P: 1996, Desafios educacionais da presente mutação tecnológica e organizacional para a formação de professores do ensino tecnológico, Formação do Educador, São Paulo: UNESP, 3.

14. Byrne, J. A: 1997, Management theory - or fad of the month, Business Week, 129, 37.

15. Hernandes, V. K: 1997, Confluências externas e internas, Psicologia Ciência e Profissão, 17, 44-52.

16. Longo, W. P. e; Telles, M. H. C. "Programa de desenvolvimento das Engenharias: Situação Atual". Revista de Ensino de Engenharia, 18. Rio de Janeiro: ABENGE,1998 p.74-82. 


\section{CLAUDIO DA ROCHA BRITO}

Claudio da Rocha Brito is a Professor of Electrical and Computer Engineering and Head of Department of University Center of Lusiada. He is Vice-President of Brazilian Chapter of Education Society of the Institute of Electrical and Electronics Engineers, Inc - IEEE - ES, Member of the Executive Committee of Ibero-American Association of Engineering Education Institutions - ASIBEI, Director of Brazilian Network of Engineering $\mathrm{RBE} / \mathrm{SP}$, Secretary of Santos region of SBPC - Brazilian Association for the Advancement of Science, Councilor of Urban Development City Council CMDU, Councilor of Metropolitan Region of Santos' Environmental Research Center - NPABS. He is also Presidency Adviser for International Relations in the ABENGE - Brazilian Society for Engineering Education. Dr. Claudio da Rocha Brito has received a B. S. degree in Electrical Engineering, B.S. degree in Mathematics, B.S. degree in Physics, M.Sc. and Ph.D. in Electrical Engineering all from the University of São Paulo. He was the General Secretary of ICECE`99 and he is the Technical Program Chairman of ICECE`2000.

\section{MELANY MARIA CIAMPI}

Melany Maria Ciampi Tenente da Rocha Brito is a Researcher of University Center of Lusiada. She is Secretary of Brazilian Chapter of Education Society of the Institute of Electrical and Electronics Engineers, Inc - IEEE - ES She belongs to the State Council of SBPC - Brazilian Association for the Advancement of Science. She has received a B. S. degree from Catholic University of Santos. She has many works in Engineering Education in several International Congresses. She was the Exhibits Chairman of ICECE`99 and she is the Publicity Chairman of ICECE`2000. 